\title{
Izabela Godyń"
}

\section{OCENA EFEKTYWNOŚCI EKONOMICZNEJ INWESTYCJI PRZECIWPOWODZIOWYCH}

\author{
EVALUATION OF THE ECONOMIC EFFICIENCY \\ OF FLOOD PROTECTION PROJECTS
}

\begin{abstract}
This article presents the problems in estimating flood losses with the use of indicators of property value published in the Regulation of 21th December 2012 issued by the Minister of the Environment, the Minister of Transport, Construction and Maritime Economy, the Minister of Administration and Digitization, and the Minister of Internal Affairs on the development of flood threat maps and flood risk maps (Journal of Laws of 2013. pos. 104). The article describes proposals of indicators updated to current prices. Also, additional indicators are proposed for estimating flood losses in agricultural production and losses of current assets of enterprises.
\end{abstract}

Key words: floods, investment efficiency, indicators.

JEL classification: Q01, Q25

\section{Wprowadzenie}

Podejmowanie decyzji inwestycyjnych w zakresie ochrony przed powodzią najczęściej oparte jest o wyniki analizy kosztów i korzyści (AKK), która ma odpowiedzieć na pytanie czy przedsięwzięcie jest efektywne ekonomicznie. Schemat analizy polega na identyfikacji i kwantyfikacji pieniężnej kosztów i korzyści związanych z realizacją i eksploatacją inwestycji, a następnie ich porównaniu i konstatacji czy dane przedsięwzięcie doprowadzi do wzrostu dobrobytu społeczności objętej jego skutkami. Zastosowanie analizy kosztów i korzyści, prostej i logicznej w swej idei, napotyka jednak na szereg trudności w przypadku przedsięwzięć z zakresu ochrony przed powodzią z uwagi na problemy z wyceną pieniężną efektów realizacji inwestycji. Efektami inwestycji przeciwpowodziowych mogą być bowiem m.in.: korzyści gospodarcze i społeczne

* Dr inż., Politechnika Krakowska, Instytut Inżynierii i Gospodarki Wodnej. 
(uniknięte straty powodziowe w majątku publicznym i prywatnym, ale także obniżenie zagrożenia życia i zdrowia mieszkańców), koszty społeczne i ekologiczne związane z budową obiektów hydrotechnicznych (przesiedlenia ludności, trwałe przekształcenie środowiska naturalnego). W przypadku inwestycji przeciwpowodziowych nawet oszacowanie podstawowych bezpośrednich korzyści - spodziewanej redukcji strat powodziowych jest metodycznie trudne. Najczęściej stosowanym podejściem szacowania unikniętych strat powodziowych jest podejście wykorzystujące jednostkowe wskaźniki wartości mienia i funkcje strat zależne od głębokości zalewu. Podejście to jest, w ostatnim czasie, szczególnie powszechne z uwagi na wprowadzenie tego typu metodyki w Rozporzqdzeniu Ministra Środowiska, Ministra Transportu, Budownictwa i Gospodarki Morskiej, Ministra Administracji i Cyfryzacji oraz Ministra Spraw Wewnętrznych z dnia 21 grudnia 2012 r. w sprawie opracowywania map zagrożenia powodziowego oraz map ryzyka powodziowego (Dz.U. z 2013 r. poz. 104).

W artykule zaprezentowano zasady oceny efektywności inwestycji przeciwpowodziowych przy wykorzystaniu AKK, przedstawiono podstawowe rodzaje kosztów i korzyści ze szczególnym uwzględnieniem głównych efektów inwestycji - unikniętych strat powodziowych i metod ich wyceny. Głównym celem artykułu jest przedstawienie problemów z szacowaniem strat powodziowych przy użyciu wskaźników wartości mienia opublikowanych w ww. rozporządzeniu wynikających z ich aktualności oraz prezentacja aktualizacji wskaźników do bieżących cen (2013 r.). Ponadto w pracy zaproponowano uwzględnienie w ocenie efektywności inwestycji unikniętych strat w majątku obrotowym przedsiębiorstw oraz bardziej dokładny szacunek strat powodziowych w produkcji rolnej prowadzony wg danych dostępnych dla województw.

\section{Analiza kosztów i korzyści przedsięwzięć przeciwpowodziowych}

Przedsięwzięcia z zakresu ochrony przed powodzią są typowymi projektami realizującymi cel publiczny, jakim jest poprawa bezpieczeństwa publicznego, finansowanymi ze środków publicznych. Powszechną metodą oceny ex-ante tego typu inwestycji jest analiza kosztów i korzyści (AKK, Cost-Benefit Analysis CBA) (zalecenia metodyczne i literaturowe: m.in. Komisja Europejska 2008, Drobniak 2008: 136-144, Grzeszczyk 2006: 255). Podstawy teoretyczne AKK to kryterium efektywności Kaldora-Hicksa, które mówi, że przedsięwzięcie publiczne jest uzasadnione wtedy, gdy osoby lub grupy społeczne, które zyskują na jego realizacji mogą (potencjalnie) wypłacić rekompensaty osobom, które poniosły koszty, dysponując nadal nadwyżką korzyści (Drobniak 2008: 67-69, 134-136, Ligus 2011: 14-15). 
Na podstawowe etapy analizy kosztów i korzyści składają się (Drobniak 2008: 145; Fołtyn-Zarychta 2008: 55-59):

- identyfikacja wszystkich kosztów i korzyści projektu,

- wycena pieniężna wszystkich kosztów i korzyści,

- zdyskontowanie przyszłych korzyści netto, co pozwala na ujęcie przyszłych kosztów i korzyści w cenach bieżących i porównanie ich z nakładami inwestycyjnymi.

Podstawową zaletą analizy kosztów i korzyści jest fakt, że koszty i korzyści są pojmowane bardzo szeroko - obejmują nie tylko wydatki i wpływy finansowe, ale także efekty w gospodarce i społeczności lokalnej oraz w środowisku naturalnym. Prognozowane, w związku z realizacją inwestycji, korzyści i koszty społeczne, gospodarcze i ekologiczne często nie generują występowania przepływów pieniężnych i nie są „wyceniane na rynku”, np. korzyści społeczne objawią się w przyszłości jako wzrost bezpieczeństwa mieszkańców, obniżenie strat powodziowych, a koszty środowiskowe jako np. trwałe przekształcenie środowiska naturalnego itd. Stąd, zaleta szerokiego patrzenia na efekty inwestycji staje się z tego powodu także wadą metody kosztów i korzyści, ponieważ szereg efektów jest trudno wycenialnych. Praktyczne stosowanie analizy AKK zależy więc od doboru odpowiednich technik i metod wyceny pieniężnej korzyści i kosztów, które nie są przedmiotem wyceny na rynku.

\section{Rodzaje kosztów i korzyści}

Pierwszym krokiem analizy AKK jest identyfikacja wszystkich kosztów i korzyści związanych z realizacją i eksploatacją inwestycji. $\mathrm{W}$ tabeli 1 przedstawiono klasyfikację kosztów i korzyści z podziałem na efekty bezpośrednie (wywołane wprost przez realizację inwestycji) i pośrednie powstające jako dodatkowy skutek inwestycji, które zwykle są trudniejsze do zidentyfikowania i wyceny.

Tabela 1. Bezpośrednie i pośrednie koszty i korzyści przedsięwzięć przeciwpowodziowych

\begin{tabular}{|c|c|}
\hline Wyszczególnienie koszty / korzyści & Przykład \\
\hline \multicolumn{2}{|c|}{ KOSZTY } \\
\hline \multicolumn{2}{|c|}{ Bezpośrednie } \\
\hline $\begin{array}{l}\text { 1. Nakłady inwestycyjne i odtworzeniowe } \\
\text { 2. Koszty eksploatacji i utrzymania } \\
\text { 3. Koszty społeczne przesiedleń } \\
\text { 4. Koszty środowiskowe }\end{array}$ & $\begin{array}{l}\text { 3. Problem utraty tzw. „małej ojczyzny” } \\
\text { 4. Zmiana warunków naturalnych ekosystemów, } \\
\text { bioróżnorodności, siedlisk, krajobrazu }\end{array}$ \\
\hline \multicolumn{2}{|c|}{ Pośrednie } \\
\hline $\begin{array}{l}\text { Zmiana / utrata charakteru obszaru np. natural- } \\
\text { nego wykorzystywanego do rekreacji / turystyki }\end{array}$ & $\begin{array}{l}\text { Spadek dochodów związanych z turystyka, } \\
\text { rekreacją na zmienionych terenach. }\end{array}$ \\
\hline
\end{tabular}


Tabela 1. cd.

\begin{tabular}{|c|c|}
\hline Wyszczególnienie koszty / korzyści & Przykład \\
\hline \multicolumn{2}{|c|}{ KORZYŚCI } \\
\hline \multicolumn{2}{|c|}{ Bezpośrednie } \\
\hline $\begin{array}{l}\text { 1. Redukcja (ograniczenie) szkód powodzio- } \\
\text { wych } \\
\text { 2. Ograniczenie strat w życiu i zdrowiu ludzi }\end{array}$ & $\begin{array}{l}\text { 1. Redukcja strat w uprawach, budynkach, dro- } \\
\text { gach, itp. }\end{array}$ \\
\hline \multicolumn{2}{|c|}{ Pośrednie } \\
\hline $\begin{array}{l}\text { 1. Redukcja (lub uniknięcie) przerw, utrudnień } \\
\text { we wszelkiego rodzaju działalności prowa- } \\
\text { dzonej na obszarze wpływu inwestycji }\end{array}$ & $\begin{array}{l}\text { 1. Redukcja strat w działalności gospodarczej, } \\
\text { systemie komunikacyjnym i sektorze usług } \\
\text { publicznych }\end{array}$ \\
\hline $\begin{array}{l}\text { 2. Ograniczenie częstości / rozmiaru akcji ra- } \\
\text { towniczych i odbudowy po powodzi }\end{array}$ & $\begin{array}{l}\text { 2. Obniżenie kosztów prowadzenia akcji ratow- } \\
\text { niczych i odbudowy zniszczeń }\end{array}$ \\
\hline $\begin{array}{l}\text { 3. Pojawienie się nowych zabezpieczonych przed } \\
\text { powodzią terenów do zagospodarowania }\end{array}$ & 3. Wzrost wartości terenu \\
\hline $\begin{array}{l}\text { 4. Wzrost bezpieczeństwa, zmniejszenie zagro- } \\
\text { żenia powodziowego }\end{array}$ & 4. Wzrost dobrobytu społeczności \\
\hline
\end{tabular}

Źródło: opracowanie własne.

Wśród wymienionych powyżej kosztów i korzyści w ocenie efektywności ekonomicznej inwestycji po stronie kosztów najczęściej uwzględniane są wydatki inwestycyjne i eksploatacyjne, pozostałe wymienione koszty są związane z oddziaływaniem na środowisko naturalne oraz społeczność lokalną. Po stronie korzyści zazwyczaj szacowane są uniknięte szkody powodziowe bezpośrednie w majątku prywatnym i publicznym.

Tabela 2. Uproszczony schemat kosztów i korzyści inwestycji

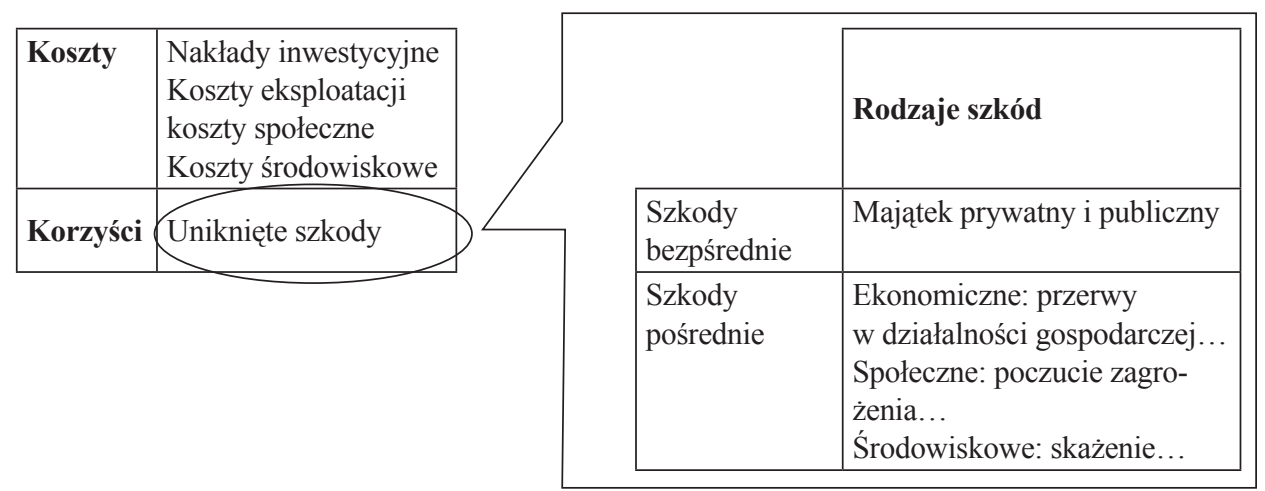

Źródto: (Lamothe i in. 2005: 29).

Jak przedstawiono powyżej w tabeli 2, szkody powodziowe dzieli się na szkody bezpośrednie i pośrednie. Bezpośrednie są powodowane przez bezpośredni kontakt wód powodziowych z nieruchomością (budynkiem, budowlą, terenem, i in.). 
Szkody powstają na skutek zalania wodą (dodatkowe znaczenie odgrywają czas i głębokość zalewu, prędkość wody oraz zanieczyszczenia znajdujące się w wodach powodziowych). Bezpośrednie zniszczenia, szkody i straty wywołują także utrudnienia w komunikacji, prowadzeniu działalności gospodarczej i dostępności usług publicznych wywołując w ten sposób powstanie pośrednich szkód powodziowych nawet na obszarach nieobjętych zalaniem.

Pełna analiza kosztów i korzyści powinna, zgodnie z jej idea, obejmować wszystkie istotne szkody i straty, najważniejsze z nich wymieniono w tabeli 3 utrzymując podział na straty bezpośrednie i pośrednie.

Tabela 3. Glówne rodzaje strat bezpośrednich i pośrednich

\begin{tabular}{|c|c|c|}
\hline & Straty bezpośrednie & Straty pośrednie \\
\hline $\begin{array}{l}\text { Zdrowie i życie } \\
\text { ludzkie }\end{array}$ & $\begin{array}{l}\text { wypadki śmiertelne (głównie utonięcia) } \\
\text { trwała lub czasowa utrata zdrowia }\end{array}$ & $\begin{array}{l}\text { koszty ewakuacji i pomocy lekarskiej } \\
\text { urazy mentalne i psychiczne (utrata } \\
\text { bliskich, poczucie zagrożenia) }\end{array}$ \\
\hline $\begin{array}{l}\text { Budynki miesz- } \\
\text { kalne }\end{array}$ & $\begin{array}{l}\text { uszkodzenia nieruchomości/budyn- } \\
\text { ków } \\
\text { strata wyposażenia i umeblowania } \\
\end{array}$ & $\begin{array}{l}\text { koszty ewakuacji i zakwaterowania, } \\
\text { wydatki na sprzątanie }\end{array}$ \\
\hline Rolnictwo & $\begin{array}{l}\text { uszkodzenia i strata zabudowań go- } \\
\text { spodarczych i in. } \\
\text { strata materiałów, narzędzi, zapasów } \\
\text { strata w uprawach } \\
\text { strata zwierząt hodowlanych }\end{array}$ & $\begin{array}{l}\text { wydatki na sprzątanie } \\
\text { straty w produkcji } \\
\text { strata - niepełne wykorzystanie zdol- } \\
\text { ności produkcyjnych }\end{array}$ \\
\hline Przemysl, handel & $\begin{array}{l}\text { uszkodzenia i strata majątku trwałego } \\
\text { strata majątku obrotowego (materiały, } \\
\text { towary, produkty gotowe i w toku) } \\
\text { strata dokumentacji, archiwów }\end{array}$ & $\begin{array}{l}\text { wydatki na sprzątanie } \\
\text { wydatki na transport, przeniesienie } \\
\text { majątku } \\
\text { straty w produkcji (straty finansowe) } \\
\text { strata - niepełne wykorzystanie zdol- } \\
\text { ności produkcyjnych }\end{array}$ \\
\hline $\begin{array}{l}\text { Uslugi publiczne, } \\
\text { infrastruktura } \\
\text { publiczna oraz } \\
\text { zaopatrzenie } \\
\text { w media }\end{array}$ & $\begin{array}{l}\text { uszkodzenia nieruchomości, budyn- } \\
\text { ków, budowli, dróg, sieci } \\
\text { strata wyposażenia }\end{array}$ & $\begin{array}{l}\text { wydatki na sprzątanie } \\
\text { wydatki na organizację alternatywne- } \\
\text { go sposobu realizacji usług publicz- } \\
\text { nych, komunikacji oraz zaopatrzenia } \\
\text { w media }\end{array}$ \\
\hline $\begin{array}{l}\text { Zabytki i dzie- } \\
\text { dzictwo kultu- } \\
\text { rowe }\end{array}$ & $\begin{array}{l}\text { uszkodzenia nieruchomości/budyn- } \\
\text { ków zabytkowych }\end{array}$ & wydatki na odtworzenie \\
\hline $\begin{array}{l}\text { Gospodarka } \\
\text { lokalna }\end{array}$ & & $\begin{array}{l}\text { spadek przyszłych przychodów, cen } \\
\text { nieruchomości, inwestycji produkcyj- } \\
\text { nych itp. }\end{array}$ \\
\hline
\end{tabular}

Źródto: opracowanie własne.

Polska literatura dot. zagadnień strat i korzyści ekologicznych wymienia straty powodziowe jako jedną z kategorii strat ekologicznych (Famielec 1999: 71; Kryk 2012: 102; Miłaszewski 2009: 347; Symonowicz 1988) jako, że w dużej 
mierze są one wywoływane działalnością człowieka (zabudowa i uszczelnienie powierzchni przyczynia się do wzrostu częstotliwości i zakresu powodzi, a rozwój zagospodarowania terenów zagrożonych powoduje wzrost potencjalnych strat powodziowych). Szacowanie strat powodziowych jest zazwyczaj prowadzone dla potrzeb oceny ex-post zaistniałych powodzi w celu wyceny strat i kosztów poniesionych ze środków publicznych (Chojnacki 2000a: 235 oraz Chojnacki 2003: 212). Sprawozdawczość GUS oraz rozliczenie pomocy publicznej udzielanej poszkodowanym najczęściej obejmuje wycenę strat w majątku publicznym (drogi, szkoły i inne budynki jednostek samorządu terytorialnego), strat w uprawach rolnych, wydatków na prowadzenie akcji przeciwpowodziowej i porządkowanie terenów po powodzi oraz wielkości udzielonej pomocy (zasiłki doraźne i remontowe). Na podstawie danych statystycznych wyznaczano wskaźniki jednostkowe strat: szacunkową wielkość strat powodziowych przypadającą na 1 ha użytków rolnych, 1 km dróg, 1 budynek mieszkalny itd., które następnie mogły być stosowane w ocenie efektywności inwestycji (Lasut 2006: 186-187, Chojnacki 2000b, Maciejewski 2000). Poniżej, w rozdziale 4 artykułu, zostaną zaprezentowane najnowsze jednostkowe wskaźniki strat/wartości mienia opublikowane w Rozporzqdzeniu z dnia 21 grudnia 2012 r. w sprawie opracowywania map zagrożenia powodziowego oraz map ryzyka powodziowego.

Jak wspomniano, wiele rodzajów szkód i strat bezpośrednich i pośrednich jest trudno wycenialnych. Część z nich to tzw. straty niewymierne - dotyczą m.in. strat bezpośrednich i pośrednich w zdrowiu i życiu ludzkim, szkód w obiektach zabytkowych i dziedzictwa kulturowego, a także tzw. strat finansowych ponoszonych przez gospodarkę na skutek zniszczenia majątku, przerw w produkcji, trudności w odtworzeniu majątku, utraty klientów itd. Tego typu straty trudno oszacować, gdyż ich charakter jest unikalny (np. zabytki), nieprzewidywalny (stres powodziowy, urazy mentalne i psychiczne), bądź też ich wycena jest kontrowersyjna i krytykowana z moralnego punktu widzenia - w szczególności dotyczy to utraty życia ludzkiego. Nowoczesne techniki wyceny efektów społecznych czy zdrowotnych dają już możliwości oszacowania wartości pieniężnych trudno mierzalnych kosztów i korzyści. Badanie kosztów związanych z utratą poczucia bezpieczeństwa, powstania tak zwanego stresu powodziowego, kosztów związanych $\mathrm{z}$ utratą pamiątek rodzinnych i in. mogą być przeprowadzane poprzez bezpośrednie badania ankietowe wśród powodzian. W 2004 r. w Wielkiej Brytanii w ramach projektu ,The appraisal of human related intangible impacts of flooding" przeprowadzono badanie $\mathrm{z}$ udziałem ponad 1500 gospodarstw domowych. Oszacowana wartość unikniętych strat związanych z utratą zdrowia lub stresem została oszacowana na $300 €$ na rok na nieruchomość (Lamothe $\mathrm{i}$ in. 2008: 51). Także tak dyskusyjna wycena jak oszacowanie życia ludzkiego jest przeprowadzana chociażby dla potrzeb rynku ubezpieczeń. W Polsce badania nad wyceną wartości statystycznego życia ludzkiego prowadził Giergiczny (2006a, 2006b). 
Pewne rodzaje strat bezpośrednich i pośrednich, nienależących do tzw. strat niewymiernych, jest trudno wycenić z uwagi na brak dostępnych danych potrzebnych do oszacowania. Wynika to głównie z braku praktyki zbierania i gromadzenia danych na temat strat i szkód powodziowych. W ramach państwowej statystyki zbierane są tylko dane dotyczące strat w infrastrukturze publicznej. Literatura zachodnia, w tym ostatnie publikacje związane z wdrożeniem Dyrektywy Powodziowej, zawiera metody, techniki i gotowe wskaźniki pozwalające na oszacowanie większości wymiernych strat bezpośrednich i pośrednich np. (Lamothe $i$ in. 2005: 37-48, Penning-Rowsell i in. 2013). Przedstawiane techniki nie mogą jednak być wprost zaimplementowane dla Polski z powodu braku wymaganych do obliczeń danych, a z kolei gotowe wskaźniki kosztowe trudno przenieść bez weryfikacji, do której także brakuje danych.

\section{Szacowanie korzyści - redukcji strat powodziowych przy wykorzystaniu wskaźników jednostkowych}

W analizie kosztów i korzyści inwestycji uwzględnia się korzyści z obniżenia zagrożenia powodziowego - unikniętych strat w rzeczowym majątku prywatnym i publicznym (budynki mieszkalne, obiekty przemysłowe, uprawy rolne, drogi, mosty, koleje itp.). Popularnym podejściem do szacowania strat powodziowych jest stosowanie jednostkowych wskaźników wartości majątku dla poszczególnych klas użytkowania terenu (form gospodarczego wykorzystania powierzchni terenu) oraz funkcji strat wiążących głębokość wody z utratą wartości majątku w danej klasie użytkowania terenu. Podejście to jest, w ostatnim czasie, szczególnie powszechne z uwagi na wprowadzenie takiej metodyki w Rozporzqdzeniu Ministra Środowiska, Ministra Transportu, Budownictwa i Gospodarki Morskiej, Ministra Administracji i Cyfryzacji oraz Ministra Spraw Wewnętrznych z dnia 21 grudnia 2012 r. w sprawie opracowywania map zagrożenia powodziowego oraz map ryzyka powodziowego (Dz.U. z 2013 r. poz. 104). Rozporządzenie reguluje co prawda zasady opracowywania map zagrożenia powodziowego, ale opublikowane wskaźniki jednostkowe są także wykorzystywane w innych rodzajach opracowań m.in. studiach wykonalności czy innych ocenach efektywności koncepcji, programów czy też pojedynczych inwestycji z zakresu ochrony przed powodzią.

Wskaźniki wprowadzone jako obowiązujące przy wyznaczaniu wartości potencjalnych strat powodziowych na potrzeby opracowania map ryzyka powodziowego w ww. rozporządzeniu zostały wyznaczone w Metodyce opracowania map ryzyka powodziowego opracowanej w 2009 r. na zlecenie Krajowego Zarządu Gospodarki Wodnej. W Metodyce... zostały opracowane wskaźniki wartości mienia dla terenów zabudowy mieszkalnej, terenów przemysłowych, rolnych, leśnych, rekreacyjnych poprzez zaadaptowanie, dla polskich realiów, wskaźników niemieckich. 
W oparciu o metodykę zalecaną w ww. rozporządzeniu oszacowaniu podlega jedynie majątek rzeczowy (w przypadku terenów przemysłowych - tylko majątek trwały - bez obrotowego). Pozostałe straty bezpośrednie i pośrednie zwykle uwzględniane są w postaci „narzutu” na straty bezpośrednie. Wskaźniki „narzutu” stosowane jako sposób uwzględnienia dodatkowych strat (poza rzeczowymi) takich jak straty w majątku ruchomym, koszty akcji powodziowych oraz usuwania szkód i porządkowania terenu. Przykładowo Chojnacki (2000) proponował, aby straty pośrednie były obliczane jako procent wartości strat bezpośrednich, zmienny w zależności od intensywności zagospodarowania - np. dla terenów miejskich zalecał: od $20 \%$ dla terenów miejskich zielonych (bez dróg i zabudowy mieszkalnej) do nawet $100 \%$ dla terenów o gęstej zabudowie i rozwiniętej sieci komunikacyjnej. Straty niewymierne takie jak utrata zdrowia i życia zazwyczaj nie podlegają wycenie.

Tabela 4. Stosowane podejścia do wyznaczania strat powodziowych

\begin{tabular}{|c|c|c|}
\hline \multicolumn{3}{|c|}{ Sposób wyznaczania strat powodziowych } \\
\hline Wskaźniki jednostkowe & $\begin{array}{l}\text { Szacowane poprzez wskaźnik } \\
\text { „narzutu” na straty rzeczowe }\end{array}$ & Niewyceniane \\
\hline Straty bezpośrednie: & Straty bezpośrednie: & Straty niewymierne: \\
\hline $\begin{array}{l}\text { Straty w majątku publicznym } \\
\text { (infrastruktura komunikacyjna, } \\
\text { tereny leśne i rekreacyjne) } \\
\text { Straty w majątku prywatnym } \\
\text { (osób fizycznych oraz przedsię- } \\
\text { biorstw) } \\
\text { Straty w rolnictwie (uprawy, } \\
\text { użytki zielone) }\end{array}$ & $\begin{array}{l}\text { Straty w majątku obrotowym } \\
\text { Straty pośrednie: } \\
\text { Straty gospodarcze wynikają- } \\
\text { ce ze zmniejszenia produkcji, } \\
\text { utrudnień w komunikacji } \\
\text { Koszty prowadzenia akcji } \\
\text { Koszty porządkowania terenów } \\
\text { po ustapieniu powodzi }\end{array}$ & $\begin{array}{l}\text { Utrata zdrowia i życia miesz- } \\
\text { kańców (utrata zdrowia, poczu- } \\
\text { cia bezpieczeństwa, komfortu } \\
\text { psychicznego, utrata życia bli- } \\
\text { skich) }\end{array}$ \\
\hline
\end{tabular}

Źródto: opracowanie własne.

\section{Wskaźniki jednostkowe wartości majątku}

Przy wyznaczaniu potencjalnych (a następnie unikniętych) strat powodziowych przy zastosowaniu metodyki proponowanej w rozporządzeniu przebieg obliczeń jest następujący:

1. Określenie obszaru objętego zagrożeniem powodziowym wraz z określeniem głębokości zalewu (przedziałów głębokości),

2. Określenie poszczególnych klas użytkowania terenu na obszarze objętym zagrożeniem powodziowym,

3. Określenie wartości majątku dla poszczególnych obszarów (na podstawie wskaźników jednostkowych),

4. Określenie strat powodziowych (na podstawie funkcji strat i głębokości). 
W rozporządzeniu wyróżniono 8 klas użytkowania terenu i przyjęto dla nich sposób wyceny strat, wskaźniki jednostkowe wartości majątku i funkcje strat. Wskaźników wartości majątku nie określono dla klasy „Wody” i „Pozostałe", dla terenów komunikacyjnych rolnych, leśnych i rekreacyjnych wyznaczono wskaźniki jednolite dla całego kraju, natomiast dla terenów mieszkalnych i przemysłowych wyznaczono wskaźniki różne dla poszczególnych województw (tabela 5).

Tabela 5. Rodzaje wskaźników wartości mienia w zależności od klasy użytkowania terenu

\begin{tabular}{|c|c|}
\hline Klasa użytkowania terenu & Podstawa określenia wartości mienia \\
\hline $\begin{array}{l}\text { Tereny zabudowy mieszkaniowej } \\
\text { Tereny przemysłowe }\end{array}$ & $\begin{array}{l}\text { Wskaźniki powierzchniowe różne dla poszcze- } \\
\text { gólnych województw }\end{array}$ \\
\hline $\begin{array}{l}\text { Tereny komunikacyjne } \\
\text { Lasy } \\
\text { Tereny rekreacyjno-wypoczynkowe } \\
\text { Użytki rolne }\end{array}$ & $\begin{array}{l}\text { Wskaźniki powierzchniowe jednolite dla całego } \\
\text { kraju }\end{array}$ \\
\hline $\begin{array}{l}\text { Wody } \\
\text { Pozostałe }\end{array}$ & Nie określa się wartości i strat \\
\hline
\end{tabular}

Źródto: opracowanie własne.

Wskaźniki wartości majątku, przyjęte w rozporządzeniu z grudnia 2012 r., są dokładnie w wysokości wskaźników określonych w Metodyce opracowania map ryzyka powodziowego (Fröhlich i in. 2009). Metodyka ta, opracowana w 2009 r., wyznaczała wskaźniki wg cen 2008, a opierała się w głównej mierze na przystosowaniu wskaźników niemieckich (z 2000 r.) do warunków polskich oraz przeliczenie ich na ceny roku 2008. W tym objawia się już pierwsza wada wskaźników rozporządzenia - nie uwzględniają one zmiany cen w latach 2008-2012, podczas gdy skumulowana inflacja za ten okres wynosi ok. 15\%. Wskaźniki są zatem zaniżone o taką wartość na moment publikacji rozporządzenia, a o około 16\% wg cen końca III kwartału 2014 r. Poniżej w podrozdziałach zostaną przedstawione inne, istotne zdaniem autorki, problemy ze stosowaniem wskaźników w ocenach efektywności inwestycji.

\section{Wskaźniki wartości majątku na terenach zabudowy mieszkaniowej}

Wskaźniki wartości majątku na terenach mieszkalnych musiały być zaadoptowane $\mathrm{z}$ innego kraju, ponieważ krajowy system statystyczny nie posiada żadnych danych dotyczących wartości mienia prywatnego. Był to zapewne główny powód sięgnięcia po wskaźniki niemieckie, które przeliczono na warunki polskie. Przeliczenia wskaźników wartości majątku na terenach mieszkaniowych na warunki polskie dokonano poprzez wskaźnik relacji polskiego i niemieckiego PKB na mieszkańca dla roku 2006 (wskaźnik wyniósł 0,45). Otrzymano wartość majątku 
80262 zł na mieszkańca (wg cen 2008 r.). Wartość ta została następnie zróżnicowana dla poszczególnych województw zgodnie z danymi GUS o relacji PKB na mieszkańca w poszczególnych województwach do średniej krajowej (Fröhlich i in. 2009).

Jak wspomniano wyżej przy publikacji rozporządzenia nie uwzględniono zmian cen w latach pomiędzy wykonaniem Metodyki (2008 r.) a ukazaniem się rozporządzenia (2012 r.). W tabeli 6 dokonano przeliczenia wskaźników wartości mienia dla poszczególnych województw wg wskaźników cen towarów i usług konsumpcyjnych z lat 2008-2013.

Tabela 6. Wskaźniki wartość mienia na terenach zabudowy mieszkalnej

\begin{tabular}{|c|c|c|c|c|c|c|c|}
\hline \multirow[b]{2}{*}{ Województwo } & \multicolumn{6}{|c|}{ Wskaźnik wartości mienia $\left[\mathrm{w} \mathbf{z l} / \mathbf{m}^{2}\right]$} & \multirow[b]{2}{*}{$\begin{array}{c}\text { Relacja } \\
\text { cen } \\
2013 / 2008\end{array}$} \\
\hline & \begin{tabular}{|c|} 
Wskaźniki \\
opublikowa- \\
ne w rozpo- \\
rządzeniu \\
ceny 2008 r. \\
\end{tabular} & $\begin{array}{c}\text { ceny } \\
2009 \text { r. }\end{array}$ & $\begin{array}{c}\text { ceny } \\
2010 \mathrm{r} \text {. }\end{array}$ & $\begin{array}{c}\text { ceny } \\
2011 \mathrm{r} .\end{array}$ & $\begin{array}{c}\text { ceny } \\
2012 \text { r. }\end{array}$ & $\begin{array}{c}\text { ceny } \\
2013 \text { r. }\end{array}$ & \\
\hline dolnośląskie & 422,24 & 437,02 & 448,38 & 467,66 & 484,96 & 489,33 & \multirow[t]{18}{*}{1,159} \\
\hline $\begin{array}{l}\text { kujawsko- } \\
\text { pomorskie }\end{array}$ & 332,72 & 344,37 & 353,32 & 368,51 & 382,15 & 385,59 & \\
\hline lubelskie & 164,54 & 170,30 & 174,73 & 182,24 & 188,98 & 190,68 & \\
\hline lubuskie & 276,30 & 285,97 & 293,41 & 306,02 & 317,35 & 320,20 & \\
\hline łódzkie & 290,94 & 301,12 & 308,95 & 322,24 & 334,16 & 337,17 & \\
\hline małopolskie & 364,09 & 376,83 & 386,63 & 403,26 & 418,18 & 421,94 & \\
\hline mazowieckie & 509,63 & 527,47 & 541,18 & 564,45 & 585,34 & 590,60 & \\
\hline opolskie & 265,87 & 275,18 & 282,33 & 294,47 & 305,37 & 308,11 & \\
\hline podkarpackie & 201,25 & 208,29 & 213,71 & 222,90 & 231,15 & 233,23 & \\
\hline podlaskie & 162,79 & 168,49 & 172,87 & 180,30 & 186,97 & 188,66 & \\
\hline pomorskie & 399,89 & 413,89 & 424,65 & 442,91 & 459,29 & 463,43 & \\
\hline śląskie & 559,03 & 578,60 & 593,64 & 619,17 & 642,08 & 647,85 & \\
\hline świętokrzyskie & 201,10 & 208,14 & 213,55 & 222,73 & 230,97 & 233,05 & \\
\hline $\begin{array}{l}\text { warmińsko- } \\
\text { mazurskie }\end{array}$ & 203,39 & 210,51 & 215,98 & 225,27 & 233,60 & 235,71 & \\
\hline wielkopolskie & 360,56 & 373,18 & 382,88 & 399,35 & 414,12 & 417,85 & \\
\hline $\begin{array}{l}\text { zachodnio- } \\
\text { pomorskie }\end{array}$ & 309,83 & 320,67 & 329,01 & 343,16 & 355,86 & 359,06 & \\
\hline \multicolumn{2}{|c|}{$\begin{array}{l}\text { wskaźnik cen towarów i usług } \\
\text { konsumpcyjnych (przy pod- } \\
\text { stawie rok poprzedni }=1 \text { ) }\end{array}$} & 1,035 & 1,026 & 1,043 & 1,037 & 1,009 & \\
\hline \multicolumn{2}{|c|}{$\begin{array}{l}\text { skumulowany wskaźnik cen } \\
\text { (rok } 2008=1 \text { ) }\end{array}$} & 1,035 & 1,062 & 1,108 & 1,149 & 1,159 & \\
\hline
\end{tabular}

Źródto: opracowanie własne. 


\section{Wskaźniki wartości majątku na terenach przemysłowych}

Wskaźniki wartości majątku na terenach przemysłowych wyznaczono dla poszczególnych województw zgodnie z danymi GUS z 2007 r. o powierzchni terenów przemysłowych oraz wartości brutto środków trwałych w przemyśle w poszczególnych województwach (Fröhlich i in. 2009). Wykonanie tych samych przeliczeń, ale według danych z 2012 r. przynosi o wiele wyższe wartości, co pokazano w tabeli 7. Ostatnie dane statystyczne opublikowane Roczniku statystycznym przemystu 2013 przedstawiają wartość majątku na koniec 2012 r. W celu wyznaczenia szacunkowej wartości środków trwałych w 2013 r. wyznaczono średni przyrost wartości w latach 2007-2012 i założono tej wysokości wzrost w 2013 roku. Wartości przedstawiono w ostatniej kolumnie tabeli 7.

Tabela 7. Wskaźniki wartości majątku na terenach przemysłowych

\begin{tabular}{|l|c|c|c|c|c|}
\hline Województwo & $\begin{array}{c}\text { Wskaźniki } \\
\text { opublikowa- } \\
\text { ne w rozpo- } \\
\text { rządzeniu } \\
\text { dane 2007 r. }\end{array}$ & $\begin{array}{c}\text { Wskaźniki } \\
\text { wg danych } \\
\text { z 2012 r. }\end{array}$ & $\begin{array}{c}\text { Relacja } \\
\text { wskaźników } \\
\mathbf{2 0 1 2 / 2 0 0 7}\end{array}$ & $\begin{array}{c}\text { Średniorocz- } \\
\text { ny wzrost } \\
\text { w latach } \\
\mathbf{2 0 0 7 - 2 0 1 2} \\
\text { [w \%] }\end{array}$ & $\begin{array}{c}\text { Wskaźniki } \\
\text { dla } \\
\mathbf{2 0 1 3} \text { r. }\end{array}$ \\
\hline dolnośląskie & 473,44 & 636,80 & 1,345 & 6,9 & 680,75 \\
\hline $\begin{array}{l}\text { kujawsko- } \\
\text { pomorskie }\end{array}$ & 461,52 & 673,24 & 1,459 & 9,2 & 735,01 \\
\hline lubelskie & 508,97 & 754,67 & 1,483 & 9,7 & 827,54 \\
\hline lubuskie & 639,37 & 828,96 & 1,297 & 5,9 & 878,13 \\
\hline łódzkie & 829,20 & 1067,42 & 1,287 & 5,7 & 1128,75 \\
\hline małopolskie & 606,64 & 826,10 & 1,362 & 7,2 & 885,87 \\
\hline mazowieckie & 943,83 & 1190,22 & 1,261 & 5,2 & 1252,36 \\
\hline opolskie & 474,32 & 565,33 & 1,192 & 3,8 & 587,02 \\
\hline podkarpackie & 641,34 & 778,30 & 1,214 & 4,3 & 811,54 \\
\hline podlaskie & 509,85 & 662,74 & 1,300 & 6,0 & 702,49 \\
\hline pomorskie & 595,82 & 882,69 & 1,481 & 9,6 & 967,68 \\
\hline śląskie & 549,65 & 783,39 & 1,425 & 8,5 & 850,02 \\
\hline świętokrzyskie & 537,68 & 781,96 & 1,454 & 9,1 & 853,01 \\
\hline $\begin{array}{l}\text { warmińsko- } \\
\text { mazurskie }\end{array}$ & 504,73 & 718,30 & 1,423 & 8,5 & 779,09 \\
\hline wielkopolskie & 702,50 & 952,68 & 1,356 & 7,1 & 1020,53 \\
\hline $\begin{array}{l}\text { zachodnio- } \\
\text { pomorskie }\end{array}$ & 326,21 & 408,07 & 1,251 & 5,0 & 428,56 \\
\hline $\begin{array}{l}\text { Średnio (na } \\
\text { podst. danych } \\
\text { dla obszaru } \\
\text { catego kraju) }\end{array}$ & 589,11 & 758,22 & 1,352 & 7,0 & 852,42 \\
\hline & & & & & \\
\hline
\end{tabular}

Źródto: opracowanie własne. 
Jak pokazują wyniki obliczeń przedstawione w tabeli 7, wskaźniki wartości majątku na terenach przemysłowych wyliczone wg danych z 2012 r. są dużo wyższe niż wynikałoby to ze zmian inflacyjnych z uwagi na ciagłe inwestycje $\mathrm{w}$ środki trwałe prowadzone przez przedsiębiorstwa.

Kolejnym ważnym aspektem, jaki należy brać pod uwagę przy stosowaniu ww. wskaźników do wyceny strat w przemyśle jest to, że wskaźniki te dotyczą jedynie majątku trwałego (wg wartości brutto). Dla wielu rodzajów działalności przemysłowej bardzo istotnym jest także majątek obrotowy, a w szczególności zapasy materiały, towary, produkcja w toku i gotowa, a ich utrata na skutek powodzi jest znacząca i dotkliwa. Poniżej w tabeli 8 przedstawiono wartość zapasów w poszczególnych rodzajach działalności przemysłowej oraz wyznaczono wskaźnik zapasy w stosunku do wartości brutto środków trwałych (wg danych GUS z 2012 r.).

Tabela 8. Wskaźniki wartości majątku obrotowego dla wybranych sekcji gospodarki

\begin{tabular}{|c|c|c|c|c|c|c|c|}
\hline \multirow{4}{*}{$\begin{array}{l}\text { Sekcje i działy } \\
\text { gospodarki }\end{array}$} & \multicolumn{5}{|c|}{ Zapasy } & \multirow{3}{*}{$\begin{array}{l}\text { Wartość } \\
\text { brutto } \\
\text { środków } \\
\text { trwałych }\end{array}$} & \multirow{4}{*}{ 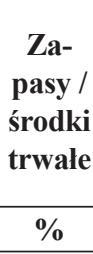 } \\
\hline & \multirow[b]{2}{*}{ razem } & \multicolumn{4}{|c|}{ w tym } & & \\
\hline & & materiały & $\begin{array}{c}\text { produkty } \\
\text { gotowe }\end{array}$ & towary & \begin{tabular}{|c|} 
pólproduk- \\
ty i produk- \\
ty w toku
\end{tabular} & & \\
\hline & \multicolumn{6}{|c|}{ mln zl } & \\
\hline OGÓŁEM & 132208 & 62030 & 36799 & 11663 & 20080 & 934305 & 14 \\
\hline $\begin{array}{l}\text { Górnictwo } \\
\text { i wydobywanie }\end{array}$ & 6040 & 981 & 2993 & 105 & 1949 & 63377 & 10 \\
\hline $\begin{array}{l}\text { Przetwórstwo } \\
\text { przemyslowe }\end{array}$ & 115342 & 53591 & 33091 & 9275 & 17869 & 515356 & 22 \\
\hline Prod.art. spożywczych & 17219 & 6439 & 6810 & 1385 & 2431 & 73860 & 23 \\
\hline $\begin{array}{l}\text { Prod. koksu i rafin. } \\
\text { ropy naft. }\end{array}$ & 17205 & 8991 & 5638 & 909 & 1667 & 35712 & 48 \\
\hline Prod. chemikaliów & 5947 & 2737 & 2118 & 447 & 522 & 33885 & 18 \\
\hline $\begin{array}{l}\text { Prod. wyr. z gumy } \\
\text { i tw. szt. }\end{array}$ & 7589 & 3405 & 2361 & 738 & 969 & 40062 & 19 \\
\hline $\begin{array}{l}\text { Prod. wyr. z poz. sur. } \\
\text { niemet. }\end{array}$ & 6072 & 2254 & 2636 & 549 & 594 & 45358 & 13 \\
\hline Prod. metali & 6623 & 3175 & 1728 & 111 & 1558 & 29116 & 23 \\
\hline $\begin{array}{l}\text { Prod. wyrobów } \\
\text { z metali }\end{array}$ & 8805 & 4493 & 1862 & 802 & 1537 & 36157 & 24 \\
\hline Prod. urządzeń elektr. & 5323 & 2558 & 1154 & 652 & 919 & 19752 & 27 \\
\hline $\begin{array}{l}\text { Prod. maszyn i urzą- } \\
\text { dzeń }\end{array}$ & 6252 & 2604 & 1116 & 407 & 1982 & 20959 & 30 \\
\hline $\begin{array}{l}\text { Prod. pojazdów sa- } \\
\text { moch. }\end{array}$ & 7168 & 4111 & 1200 & 542 & 1230 & 49375 & 15 \\
\hline $\begin{array}{l}\text { Wytw. i zaopatr. } \\
\text { w en.el., gaz, parę } \\
\text { i gorącą wodę }\end{array}$ & 10009 & 7003 & 636 & 2099 & 188 & 230146 & 4 \\
\hline
\end{tabular}

Źródto: opracowanie własne. 


\section{Wskaźniki wartości majątku na terenach rolnych}

Wartość majątku na terenach wykorzystywanych rolniczo (a zarazem straty powodziowe $\mathrm{w}$ produkcji rolnej) $\mathrm{w} w \mathrm{w}$. rozporządzeniu przyjęto na poziomie 1428 zł na 1 ha gruntów ornych oraz 674 zł na 1 ha użytków zielonych. Wskaźniki te wyznaczono na podstawie wskaźników niemieckich, ale są one bliskie wielkościom wyznaczonym na podstawie całkowitej wartości produkcji rolnej w skali kraju i całkowitej powierzchni gruntów rolnych (w podziale na grunty orne i łąki). Są jednolite dla wszystkich województw - w przeciwieństwie do wskaźników strat na terenach przemysłowych i terenach zabudowy mieszkalnej, które zostały wyznaczone o wartości charakterystyczne dla poszczególnych województw (wartość majątku trwałego przedsiębiorstw, powierzchnia terenów przemysłowych, liczba ludności i in.) i są różne w województwach. Nie uwzględniono specyfiki produkcji rolnej w poszczególnych województwach, chociaż są dostępne na poziomie województw dane o powierzchniach gruntów dla różnego rodzaju zasiewów, wielkości produkcji i cenach produkcji rolnej.

W celu oceny wskaźników przyjętych w rozporządzeniu wyznaczono wskaźniki rzeczywiste strat jednostkowych w rolnictwie na podstawie danych o rzeczywistych stratach powodziowych w rolnictwie w województwie małopolskim oraz w wybranych gminach województwa świętokrzyskiego (z ostatnich lat). Wskaźnik jednostkowy dla województwa małopolskiego wyznaczono na podstawie publikacji Urzędu Statystycznego w Krakowie (US 2011) i wynosi 3914 zł/ha (straty w uprawach 324,83 mln zł, powierzchnia upraw 83 tys. ha). Wartość wskaźnika jest prawie 3-krotnie wyższa niż zalecana $\mathrm{w}$ rozporządzeniu dla strat na gruntach ornych.

Dane zebrane z gmin województwa świętokrzyskiego (Dwikozy, Klimontów, Koprzywnica, Łoniów, Samborzec, Sandomierz, Wilczyce i Zawichost) dotyczyły gmin rolniczych, w których rozwinięta jest specjalistyczna produkcja rolna sadownictwo, warzywa gruntowe i uprawy pod folią. Informacje zebrane z tych gmin pozwoliły na wyznaczenie wskaźników rzeczywistych strat, jakie wystapiły w ostatnich latach - wyniki przedstawiono w tabeli 9.

Tabela 9. Rzeczywiste wskaźniki strat powodziowych na terenach rolnych w wybranych rolniczych gminach woj. świętokrzyskiego

\begin{tabular}{|l|c|c|c|}
\hline \multirow{2}{*}{ Gmina / okres powodzi } & $\begin{array}{c}\text { Pow. zalanych } \\
\text { gruntów rolnych }\end{array}$ & Straty & Wskaźnik strat \\
\cline { 2 - 4 } & {$[\mathbf{h a ]}$} & {$[\mathbf{z l}]$} & [zl/ha] \\
\hline Dwikozy / maj-czerwiec 2010 & 847,65 & 34020515 & 40135 \\
\hline Klimontów / czerwiec 2009 & 330,99 & 1768399 & 5343 \\
\hline Koprzywnica / czerwiec 2009 & 58,56 & 267048 & 4560 \\
\hline Koprzywnica / maj-czerwiec 2010 & 316,4 & 2165371 & 6844 \\
\hline Łoniów / maj 2010 & 781,83 & 4862505 & 6219 \\
\hline
\end{tabular}


Tabela 9. cd.

\begin{tabular}{|l|c|c|c|}
\hline \multirow{2}{*}{ Gmina / okres powodzi } & $\begin{array}{c}\text { Pow. zalanych } \\
\text { gruntów rolnych }\end{array}$ & Straty & Wskaźnik strat \\
\cline { 2 - 4 } & {$[\mathbf{h a ]}$} & \multicolumn{1}{|c|}{$[\mathbf{z l}]$} & {$[\mathbf{z l} / \mathbf{h a}]$} \\
\hline Łoniów / sierpień-wrzesień 2010 & 120,91 & 1094604 & 9053 \\
\hline Samborzec / maj-czerwiec 2010 & 2018,98 & 25392349 & 12577 \\
\hline Sandomierz / maj-czerwiec 2010 & 263,96 & 3294089 & 12480 \\
\hline Wilczyce / maj 2008 & 180,43 & 644755 & 3573 \\
\hline Wilczyce / maj 2010 & 394,35 & 3285896 & 8332 \\
\hline Zawichost / maj-czerwiec 2010 & 230,85 & 1876311 & 8128 \\
\hline Ogółem pow. i straty, średni wskaźnik & $\mathbf{5 5 4 4 , 9 1}$ & $\mathbf{7 8 ~ 6 7 1 ~ 8 4 2}$ & $\mathbf{1 4 ~ 1 8 8}$ \\
\hline
\end{tabular}

Źródło: opracowanie własne.

Przedstawione w tabeli 9 rzeczywiste wskaźniki wartości strat są wysokie $\mathrm{z}$ uwagi na charakter upraw, w gminach powiatu sandomierskiego wskaźniki strat w produkcji na gruntach rolnych wahają się od 3,6 do 40,1 tys. zł/ha wobec 1,4 tys. zł/ha przyjmowanych w rozporządzeniu. Prezentowane wyniki dowodza, że dla potrzeb oceny efektywności inwestycji przeciwpowodziowych należy prowadzić oszacowanie potencjalnych strat powodziowych w oparciu o dane rzeczywistym profilu produkcji rolnej i/lub wskaźnikach historycznych.

$\mathrm{Na}$ podstawie danych statystycznych opublikowanych w Roczniku Statystycznym Rolnictwa 2013 oszacowano wskaźniki wartości produkcji rolnej w podziale na województwa. Przeliczeń dokonano wyodrębniając dwa rodzaje gruntów: sady oraz pozostałe grunty rolne, taki podział jest uzasadniony z dwóch powodów: po pierwsze - do identyfikacji klasy użytkowania terenu wykorzystywana Baza Danych Obiektów Topograficznych (BDOT), w której klasa typu „sad” jest wyróżniona, nie należy zatem dążyć do agregacji tej grupy gruntów z pozostałymi gruntami ornymi, tracąc przy tym informację o profilu produkcji, drugim istotnym argumentem jest fakt, że wartość produkcji na terenach sadów - wartość produkcji owoców jest kilkakrotnie wyższa niż produkcja zbóż lub innych upraw.

Do wyznaczenia wskaźników wartości produkcji rolnej wykorzystano dane o wartości globalnej produkcji rolnej oraz strukturze produkcji według produktów i województw. Najnowsze publikowane dane pokazują strukturę produkcji rolniczej w 2011 r., wyznaczono wskaźniki wg danych z 2011 r. o wartości produkcji i wykorzystaniu gruntów, dodatkowo wyznaczono wskaźniki dla 2012 r. zakładając tę samą strukturę produkcji co w 2011 r., ale przy uwzględnieniu wartości produkcji oraz danych o wykorzystaniu gruntów w 2012 r. Przedstawiono również dane dotyczące wyników produkcji rolnej w 2010 r. Wartość produkcji rolnej nie ma stałej wyraźnej tendencji wzrostowej (w przeciwieństwie do analizowanych wcześniej wskaźników wartości mienia na terenach mieszkalnych i przemysłowych). Wynika to z wielu powodów - wielkość produkcji jest za- 
leżna od występujących $\mathrm{w}$ danym roku warunków meteorologicznych, sytuacji na rynku produktów rolnych krajowym a także zagranicą (popytu i podaży, cen żywności, a także środków wykorzystywanych w produkcji rolnej). $Z$ tego powodu do wyceny wartości produkcji raczej należy się posługiwać wielkościami średnimi z ostatnich lat niż danymi z jednego roku - takie podejście zalecane przez Ministerstwo Rolnictwa komisjom powoływanym przez wojewodów do wyceny szkód w gospodarstwach rolnych powodowanych przez suszę, grad, przymrozki, powódź i in. Informacja dla komisji przedstawia wartość produkcji rolnej na 1 ha w poszczególnych województwach jako wartość średnią z ostatnich 3 lat. Wyniki przeliczeń przedstawiono $\mathrm{w}$ tabeli 10 .

Tabela 10. Wskaźniki wartości produkcji rolnej w województwach

\begin{tabular}{|c|c|c|c|c|c|c|c|c|}
\hline \multirow{3}{*}{ Województwo } & \multicolumn{8}{|c|}{ Wskaźnik wartości produkcji rolnej w [w zl/ha] } \\
\hline & \multicolumn{2}{|c|}{2010} & \multicolumn{2}{|c|}{2011} & \multicolumn{2}{|c|}{2012} & \multicolumn{2}{|c|}{$\begin{array}{c}\text { Średnio } \\
2010-2012\end{array}$} \\
\hline & sady & $\begin{array}{c}\text { grunty } \\
\text { orne }\end{array}$ & sady & $\begin{array}{c}\text { grunty } \\
\text { orne }\end{array}$ & sady & $\begin{array}{c}\text { grunty } \\
\text { orne }\end{array}$ & sady & $\begin{array}{c}\text { grunty } \\
\text { orne }\end{array}$ \\
\hline dolnośląskie & 8981 & 3752 & 16085 & 4458 & 13890 & 4528 & 12985 & 4246 \\
\hline kujawsko-pomorskie & 4885 & 3561 & 4662 & 4240 & 4052 & 4543 & 4510 & 4115 \\
\hline lubelskie & 26357 & 3543 & 44067 & 4291 & 37738 & 4656 & 32210 & 4163 \\
\hline lubuskie & 11203 & 2883 & 11967 & 2950 & 10124 & 3155 & 10950 & 2996 \\
\hline lódzkie & 15182 & 3989 & 20553 & 4806 & 17612 & 5091 & 16719 & 4629 \\
\hline małopolskie & 3492 & 4818 & 8272 & 5867 & 7095 & 8096 & 5847 & 6260 \\
\hline mazowieckie & 12056 & 4004 & 23760 & 4550 & 19624 & 4919 & 16709 & 4491 \\
\hline opolskie & 6052 & 3755 & 5291 & 4940 & 4505 & 5157 & 5459 & 4617 \\
\hline podkarpackie & 5678 & 2812 & 9046 & 2889 & 7839 & 3668 & 7091 & 3123 \\
\hline podlaskie & 6566 & 2274 & 8702 & 2195 & 7434 & 2485 & 7223 & 2318 \\
\hline pomorskie & 5168 & 3180 & 7710 & 3470 & 6554 & 3647 & 6053 & 3432 \\
\hline śląskie & 3793 & 3353 & 7486 & 3938 & 6745 & 4910 & 6240 & 4067 \\
\hline świętokrzyskie & 7950 & 3860 & 13698 & 4760 & 11214 & 5482 & 10649 & 4700 \\
\hline warmińsko-mazurskie & 12964 & 2704 & 15410 & 2398 & 13180 & 3039 & 13072 & 2714 \\
\hline wielkopolskie & 5811 & 3760 & 3989 & 3906 & 3450 & 3897 & 4572 & 3854 \\
\hline zachodniopomorskie & 9656 & 2770 & 11860 & 2842 & 10493 & 2977 & 10724 & 2863 \\
\hline
\end{tabular}

Źródto: opracowanie wtasne.

Dane zestawione w tabeli 10 pokazują, że średnia (z ostatnich 3 lat) wartość produkcji rolnej, a tym samym potencjalnych strat powodziowych, na 1 ha sadów waha się od 4,5 do 32 tys. zł, na gruntach od 2,3 do 6,3 tys. zł. Wartości średnie są wyliczone między innymi na podstawie roku 2010, który w wielu województwach przyniósł znacząco niższe plony z powodu katastrofalnej powodzi, jaka wtedy wystąpiła, jednakże pomimo tego wskaźniki są wielokrotnie wyższe od wskaźnika zalecanego w rozporządzeniu. 


\section{Podsumowanie}

Ocena efektywności inwestycji przeciwpowodziowych polega na identyfikacji i wycenie pieniężnej wszystkich istotnych efektów inwestycji - bezpośrednich i pośrednich ekonomicznych, ekologicznych oraz społecznych kosztów i korzyści wynikających z realizacji projektu i porównaniu ich z nakładami inwestycyjnymi i kosztami późniejszej eksploatacji. Przy sporządzaniu oceny poważnym problemem jest wiarygodna ocena ilościowa i/lub pieniężna większości kosztów i korzyści. Szereg efektów jest niewymiernych (życie i zdrowie ludzkie), trudnych do oszacowania (korzyści pośrednie, koszty środowiskowe), brakuje danych np. na temat historycznych strat powodziowych w majątku prywatnym. Już na etapie określania podstawowych bezpośrednich korzyści - spodziewanej redukcji strat powodziowych, występują znaczące problemy z ich oszacowaniem. Stosowane techniki szacowania strat powodziowych wynikają ze skali przedsięwzięć i dostępności niezbędnych do analizy danych. Najczęściej przy dużej skali oddziaływania inwestycji analiza opiera się na jednostkowych wskaźnikach wartości majątku $\mathrm{W}$ zależności od rodzaju zagospodarowania terenu. W artykule przedstawiono problemy z szacowaniem strat powodziowych w oparciu o wskaźniki jednostkowe wartości majątku, opublikowane w Rozporządzeniu z 21 grudnia 2012 r. w sprawie opracowywania map zagrożenia powodziowego oraz map ryzyka powodziowego. Podstawowe wnioski z analizy wskaźników są następujące:

- Wskaźniki wartości majątku na terenach mieszkalnych:

- publikowane w rozporządzeniu są niskie, odzwierciedlają poziom cen 2008 r.;

- propozycja modyfikacji wskaźników dla oceny inwestycji - aktualizacji wskaźników do cen bieżących, np. wskaźnik inflacji 2013/2008 = 1,16;

- Wskaźniki wartości majątku na terenach przemysłowych:

- publikowane w rozporządzeniu są niskie, odzwierciedlają poziom cen 2008 r.;

- propozycja wskaźników dla oceny inwestycji:

- dla inwestycji w skali lokalnej - uzupełnienie informacji z bezpośredniego kontaktu z przedsiębiorstwami i/lub obliczenie zaktualizowanych wskaźników na podstawie aktualnej wartości majątku trwałego (zazwyczaj wzrost środków trwałych » inflacji) wg danych statystycznych BDL GUS;

- dla inwestycji w skali regionalnej-obliczenie zaktualizowanych wskaźników na podstawie aktualnej wartości majątku trwałego wg danych statystycznych BDL GUS;

- Wskaźniki wartości majątku na terenach rolniczych:

- publikowane $\mathrm{w}$ rozporządzeniu są niskie, odzwierciedlają poziom cen 2008 r.;

- propozycja wskaźników dla oceny inwestycji: 
- Skala lokalna - dane z ostatniego Spisu rolnego (uprawy)

- Skala regionalna - dane statystyczne GUS dla województw (grunty orne/ łąki, plony z ha).

Sporządzając analizę kosztów i korzyści należy pamiętać o przyjętych założeniach, a w szczególności o dokonanych uproszczeniach - niewycenionych korzyściach i kosztach. A przedstawiając wynik oceny efektywności - pokazujący saldo dodatnie lub ujemne korzyści nad kosztami, warto dodać informację o pominiętych w wycenie korzyściach i kosztach.

\section{Bibliografia}

Biedroń I., Bogdańska-Warmuz R. (2012), Powódź 2010 - analiza strat i szkód powodziowych $w$ Polsce, Gospodarka wodna nr 4/2012.

Chojnacki J. (2000a), Ogólna analiza strat z powodzi czerwcowo-lipcowej 1999 r., Gospodarka wodna $\mathrm{nr}$ 6/2000: 234-235.

Chojnacki J. (2000b), Szacowanie przewidywanych strat powodziowych $w$ terenach zurbanizowanych metodq typizacji zagospodarowania obszarów zagrożonych, Gospodarka wodna nr 10/2000: 368-373.

Chojnacki J. (2003), Charakterystyka strat powodziowych w kraju w 2001 r., Gospodarka wodna nr 5/2003: 211-212.

Drobniak A. (2008), Podstawy oceny efektywności projektów publicznych, Wydawnictwo Akademii Ekonomicznej w Katowicach, Katowice.

Famielec J. (1999), Straty i korzyści ekologiczne w gospodarce narodowej, Wydawnictwo Naukowe PWN, Warszawa-Kraków.

Foltyn-Zarychta M. (2008), Analiza kosztów-korzyści w ocenie efektywności inwestycji proekologicznych, Wydawnictwo Akademii Ekonomicznej w Katowicach, Katowice.

Fröhlich K., Kwiatkowski J., Spatka J., Zeman E., Żylicz T. (2009), Metodyka opracowania map ryzyka powodziowego, Krajowy Zarząd Gospodarki Wodnej, Warszawa.

Genovese E. (2006), A methodological approach to land use-based flood damage assessment in urban areas: Prague case study, http://www.preventionweb.net.

Giergiczny M. (2006a), Wycena wartości statystycznego życia ludzkiego z wykorzystaniem metody wyceny hedonicznej, Ekonomia i Środowisko 1(29): 60-74.

Giergiczny M. (2006b), Wycena wartości statystycznego życia ludzkiego z wykorzystaniem metody wyborów z eksperymentami, Ekonomia i Środowisko 2(30): 42-56.

Global Water Partnership \& World Meteorological Organization - WMO (2007), Economic Aspects of Integrated Flood management.

Grzeszczyk T. (2006), Metody oceny projektów z dofinansowaniem Unii Europejskiej, Placet, Warszawa. Komisja Europejska (2008), Przewodnik do analizy kosztów i korzyści projektów inwestycyjnych.

Kryk B. (red.) (2012) Gospodarowanie i zarzqdzanie środowiskiem, Wydawnictwo Naukowe Uniwersytetu Szczecińskiego, Szczecin.

Lamothe D.N., Neveu G., Gorlach B., Interwies E. (2005), Evaluation of the impact of floods and associated protection policies, European Commission DG Environment.

Ligus M. (2011), Efektywność inwestycji w odnawialne źródła energii. Analiza kosztów i korzyści, CeDeWu.pl, Warszawa.

Łasut A. (2006), Koszty i korzyści z wprowadzenia w Polsce systemu ubezpieczeń obowiqzkowych od skutków powodzi, rozprawa doktorska, AGH Wydział Zarządzania, Kraków. 
Maciejewski M. (2000), Model kompleksowej ochrony przed powodziq, IMGW, Kraków.

Michalak A. (2007), Finansowanie inwestycji w teorii i praktyce, PWN, Warszawa.

Miłaszewski R. (2009), Metody określania kosztów środowiskowych i zasobowych spowodowanych użytkowaniem wód, Rocznik Ochrona Środowiska, tom $11: 339-353$.

Penning-Rowsell E., Johnson C., Tunstall S., Tapsell S., Morris J., Chatterton J., Green C. (2005), The Benefits of Flood and Coastal Risk Management: A Handbook of Assessment Techniques, Middlesex University Press.

Rozporządzenie Ministra Środowiska, Ministra Transportu, Budownictwa i Gospodarki Morskiej, Ministra Administracji i Cyfryzacji oraz Ministra Spraw Wewnętrznych z dnia 21 grudnia 2012 r. w sprawie opracowywania map zagrożenia powodziowego oraz map ryzyka powodziowego (Dz.U. z 2013 r. poz. 104).

Symonowicz A. (1988), Straty z tytulu degradacji środowiska. Ich charakterystyka i próby szacun$k u$, w: Ekonomiczne i socjologiczne problemy ochrony środowiska, pod redakcją A. Ginsberta-Geberta, Ossolineum, Wrocław.

US (2011), Powódź w województwie małopolskim w 2010 roku, Urząd Statystyczny w Krakowie, Kraków.

\section{Streszczenie}

W artykule przedstawiono problemy z szacowaniem strat powodziowych przy użyciu wskaźników wartości mienia opublikowanych w Rozporządzeniu Ministra Środowiska, Ministra Transportu, Budownictwa i Gospodarki Morskiej, Ministra Administracji i Cyfryzacji oraz Ministra Spraw Wewnętrznych z dnia 21 grudnia 2012 r. w sprawie opracowywania map zagrożenia powodziowego oraz map ryzyka powodziowego (Dz.U. z 2013 r. poz. 104) wynikające z ich aktualności i zaprezentowano propozycje aktualizacji wskaźników do bieżących cen, a także zaproponowano dodatkowe wskaźniki szacowania strat powodziowych w produkcji rolnej oraz strat w majątku obrotowym przedsiębiorstw.

Słowa kluczowe: powodzie, efektywność inwestycji wskaźniki

Numer klasyfikacji JEL: Q01, Q25 